\title{
Systemic treatment of HER2-positive breast cancer patients with brain metastases: current status and exploratory case study in a Portuguese cohort
}

\author{
Tratamento sistémico do carcinoma de mama HER2 positivo com metástases cerebrais: estado atual \\ e estudo exploratório de casos numa coorte portuguesa
}

\author{
Paulo Luz ${ }^{1,2}$ ", Elsa Campoa ${ }^{1}$, Rita Gameiro ${ }^{3}$, Marta Vaz ${ }^{4}$, Isabel Fernandes ${ }^{3}$, Joana Magalhães ${ }^{1}$, Beatriz \\ Gosalbez $^{1}$, Sofia Braga ${ }^{4}$, João Guilherme Costa ${ }^{2}$, Ana Sofia Fernandes ${ }^{2}$ \\ ${ }^{1}$ Centro Hospitalar Universitário do Algarve, Medical Oncology; \\ ${ }^{2}$ CBIOS - Universidade Lusófona's Research Center for Biosciences \& Health Technologies, Lisboa, Portugal \\ ${ }^{3}$ Centro Hospitalar Barreiro-Montijo, Medical Oncology \\ ${ }^{4}$ Hospital Fernando Fonseca EPE, Medical Oncology \\ *corresponding author:p_luz@msn.com
}

\begin{abstract}
Over the last years, the incidence of brain metastases in HER2 breast cancer patients has increased. Surgery and radiotherapy are the current standard local therapies. Nevertheless, it is unclear which and when systemic treatment should be applied in addition to local treatment. This work aims to present an updated review of current systemic treatment options for patients with HER2+ metastatic breast cancer with brain metastases and to present a case study of clinical cases that occurred in a Portuguese population.

The methodology of this work included a literature search in PubMed for the impact of HER2-targeting agents, such as pertuzumab, trastuzumab emtansine (T-DM1), lapatinib, neratinib, trastuzumab deruxtecan, and tucatinib in the treatment of patients with HER2+ breast cancer with brain metastases. Then, a cohort of Portuguese patients with HER2+ breast cancer $(n=44)$ was analyzed. In this exploratory study, considering a follow-up of 23.9 months, three patients $(6.8 \%)$ developed brain metastases despite having shown a complete pathological response. The role of systemic treatment for patients with HER2 breast cancer with brain metastases has rapidly evolved following recent successes in phase II and III clinical trials. The biggest challenge is how to integrate systemic and local treatment in the management of these patients.
\end{abstract}

Keywords: Brain metastases, breast cancer, HER2, trastuzumab deruxtecan, tucatinib

\begin{abstract}
Resumo
Nos últimos anos, a incidência de metástases cerebrais em doentes com cancro da mama HER2 tem aumentado. A cirurgia e a radioterapia continuam a ser os tratamentos preferenciais. No entanto, não é claro que tratamento sistémico, para além do tratamento local, deve ser aplicado e quando. Este trabalho visa apresentar uma revisão das atuais opções de tratamento sistémico nos doentes com cancro da mama metastático HER2+ com metástases cerebrais e apresentar casos clínicos ocorridos numa amostra da população portuguesa.

A metodologia deste trabalho incluiu uma pesquisa bibliográfica no PubMed sobre o impacto de agentes anti-HER2, tais como pertuzumab, trastuzumab-emtansina (T-DM1), lapatinib, neratinib, trastuzumab-deruxtecan, e tucatinib no tratamento de doentes com cancro da mama HER2+ com metástases cerebrais. Seguidamente, foi também analisada uma coorte de doentes portugueses com cancro da mama HER2+ $(n=44)$. Neste estudo exploratório, considerando um seguimento médio de 23,9 meses, três pacientes $(6,8 \%)$ desenvolveram metástases cerebrais, apesar de terem apresentado resposta patológica completa. O papel do tratamento sistémico em doentes com cancro da mama HER2 com metástases cerebrais evoluiu rapidamente, após os recentes sucessos em ensaios clínicos de fase II e III. O maior desafio é o de integrar o tratamento sistémico e local na gestão destes doentes.
\end{abstract}

Palavras-chave: metástases cerebrais, cancro da mama, HER2, trastuzumab deruxtecan, tucatinib 


\section{Introduction}

Up to $15 \%$ of all patients with metastatic breast cancer (BC) will develop brain metastases during the course of their disease. The molecular subtypes with a higher risk of developing brain metastases are triple-negative breast cancer and HER2+ tumors (1). The incidence of brain metastases has been rising over the last years, commonly attributed to the excellent systemic control that increases the overall survival (OS) of BC patients. According to several studies, the presence of brain metastases in HER2+ BC occurs in about 10-14\% after diagnosis of early-stage disease and $28-41 \%$ in metastatic settings $(1,2)$.

In terms of survival, a retrospective study carried out at Institut Jules Bordet, Belgium, with 483 patients, 72 of which had brain metastasis, revealed an overall survival (OS) of 20.8 months, compared with 46.7 months of OS in the group of patients with metastatic disease without disease in the brain (1). Over the years, therapeutic developments, namely anti-HER 2 therapies, have changed the paradigm associated with this tumor subtype and its OS. With these developments, there was an increase in OS from 2-16 months to 14-24 months (3).

For treating brain metastasis, surgical intervention is preferable whenever possible, namely in single lesions with small size and easy surgical access (3), although radiotherapy is also an option. In randomized trials that included patients with lung and breast cancer, the median survival in patients treated with whole-brain radiotherapy (WBRT) ranges from four to six months, at the cost of some relevant toxicity, namely cognitive impairment (4-6). The development of stereotactic techniques has also significantly improved the quality of life of these patients, associated with less neurological toxicity (1-3). With the advent of multiple therapies, the paradigm has changed. New systemic approaches have been shown to increase patient survival and the maintenance of functionality in daily activities $(1,3)$.

This article aims to review the different systemic therapies currently available for the treatment of HER2+ $\mathrm{BC}$ patients with brain metastases (BM). Moreover, a cohort of Portuguese patients with HER2+ breast cancer was analyzed and a case study of the patients that developed BM is presented.

\section{Introdução}

Até $15 \%$ de todas as doentes com cancro da mama (CM) metastásico, desenvolverão metástases cerebrais durante o curso da doença. Os subtipos moleculares com maior risco de desenvolver metástases cerebrais são o CM triplo-negativo e os tumores HER2+ (1). A incidência de metástases cerebrais tem vindo a crescer nos últimos anos, em parte devido ao excelente controlo sistémico que aumenta a sobrevivência global (SG) deste doentes. De acordo com vários estudos, o cancro de mama HER $2+$ representa 20 a $25 \%$ de todos os subtipos sendo que a presença de metástases cerebrais ocorre em cerca de $10-14 \%$ após o diagnóstico em estadio precoce, e $28-41 \%$ em contexto metastático $(1,2)$.

Em termos de sobrevivência, um estudo retrospetivo realizado no Institut Jules Bordet, na Bélgica, com 483 pacientes, 72 dos quais com metástases cerebrais, mostrou uma SG de 20,8 meses, em comparação com 46,7 meses no grupo de pacientes com doença metastática sem doença a nivel cerebral (1). Ao longo dos anos, o desenvolvimento de novas terapêuticas, nomeadamente moléculas anti-HER2, alteraram o paradigma associado a este subtipo e à sua $\mathrm{SG}$. Com estes avanços, houve um aumento da SG de 2-16 meses para 14-24 meses (3).

Para o tratamento das metástases cerebrais, sempre que possível, é preferível a intervenção cirúrgica, nomeadamente em lesões únicas com tamanho reduzido e fácil acesso cirúrgico (3), embora a radioterapia seja também uma opção. Em ensaios randomizados que incluíram doentes com cancro do pulmão e da mama, a sobrevivência média em doentes tratadas com radioterapia holocraneana variou entre quatro e seis meses, ao custo de toxicidade importante como a deterioração cognitiva $(4,5,6)$. O desenvolvimento de técnicas estereotáxicas também melhorou significativamente a qualidade de vida destas pacientes, associada a uma menor toxicidade neurológica $(1,2,3)$ Com o aparecimento de múltiplas terapias, o paradigma mudou e novas abordagens sistémicas mostraram aumentar a sobrevivência das pacientes e preservar a qualidade de vida $(1,3)$.

Este artigo visa rever as diferentes opções terapêuticas para o tratamento de doentes com CM HER2+ com metástases cerebrais. Além disso, é analisada uma coorte de doentes portuguesas com cancro de mama HER2+, e apresentado um estudo clínico com as doentes que desenvolveram metástases cerebrais. 


\section{Materials and Methods}

\section{Literature review}

A literature search in the PubMed database, using the keywords "HER2 breast cancer" and "brain metastases" was conducted. Articles published in English between January 2006 and June 2020 were selected. In this narrative review, original articles were selected based on their clinical and scientific relevance. The objective was to describe the impact of the HER2targeting agents pertuzumab, trastuzumab emtansine (T-DM1), lapatinib, neratinib, trastuzumab deruxtecan and, tucatinib on the treatment of patients with HER2+ breast cancer and BM.

\section{Observational study}

Patients with HER2+ BC who were diagnosed and treated at Centro Hospital Universitário do Algarve and Centro Hospitalar Barreiro-Montijo between January 2018 and December 2019, were included in this study. Additional inclusion criteria were patients with HER2+ breast carcinoma, submitted to neoadjuvant therapy with double anti-HER2 block with trastuzumab and pertuzumab, followed by surgery. We excluded patients with stage IV disease at diagnosis and patients who progressed during neoadjuvant therapy.

The following parameters were analyzed by reviewing the electronic medical records of the patients and according to oncology and pathology services protocols: initial stage, lymph nodes status, expression of hormone receptors, Ki-67, type of surgery, type of adjuvant therapy, distant recurrence, and pathological response. The cases where brain metastases were detected during this preliminary follow-up were characterized. Descriptive statistics were used whenever appropriate.

\section{Results and Discussion}

According to our literature research, the following HER2-targeting agents may be used in the treatment of patients with HER2+ breast cancer and brain metastases: pertuzumab, trastuzumab emtansine (TDM1), lapatinib, neratinib, trastuzumab deruxtecan and, tucatinib. In the following sub-sections, the clinical use of these drugs for this purpose is reviewed.

\section{Material e Métodos}

\section{Revisão de literatura}

Foi realizada uma pesquisa bibliográfica na base de dados PubMed usando as palavras-chave "HER2 breast cancer" e "brain metastases". Foram seleccionados artigos publicados em inglês entre Janeiro 2006 e Junho 2020. Nesta revisão narrativa, foram selecionados artigos originais com base na sua relevância clínica e científica. O objetivo foi descrever o impacto dos vários agentes anti HER2, pertuzumab, trastuzumabemtansina (T-DM1), lapatinib, neratinib, trastuzumab deruxtecan e tucatinib, no tratamento de doentes com cancro da mama HER2+ e metástases cerebrais.

\section{Estudo observacional}

Analisámos doentes com CM HER2+, diagnosticadas e tratadas no Centro Hospitalar Universitário do Algarve e Centro Hospitalar Barreiro-Montijo, entre Janeiro 2018 e Dezembro 2019. Foram incluídas doentes com CM HER2+, submetidas a tratamento neoadjuvante com duplo bloqueio anti-HER2 com trastuzumab e pertuzumab, seguida de cirurgia. Foram excluídas doentes com CM HER2+ estádio IV ao diagnóstico ou que progrediram durante o tratamento neoadjuvante.

Foram analisados os seguintes parâmetros, através da consulta aos processos clínicos electrónicos e de acordo com os protocolos dos serviços de oncologia e anatomia patológica: estadio inicial, expressão dos recetores hormonais, Ki-67, tipo de cirurgia, tratamento adjuvante, recidiva a distância e resposta patológica. Foram caracterizados os casos em que foram detetadas metástases cerebrais durante o seguimento.

\section{Resultados e Discussão}

De acordo com a nossa pesquisa na literatura, os seguintes agentes anti-HER2 podem ser usados no tratamento de doentes com CM HER2+ e metástases cerebrais: pertuzumab, trastuzumab emtansina ( $\mathrm{T}$ DM1), lapatinib, neratinib, trastuzumab deruxtecan e tucatinib. Nas subseções a seguir, é revista a evidência científica sobre a utilização destes fármacos neste contexto. 


\section{Monoclonal antibodies}

\section{Pertuzumab}

Pertuzumab is a monoclonal antibody that prevents heterodimerization of the HER2 receptor with other receptors in the EGFR family (8). The study that led to its approval in first-line treatment for patients with metastatic HER2+ BC (CLEOPATRA) excluded patients with brain metastases. However, in the followup of these patients, it was found that therapy with trastuzumab, pertuzumab, and docetaxel did not reduce the incidence of brain metastasis but delayed its onset (11.9 months in the placebo group versus (vs.) 15 months in the pertuzumab-treated group, $\mathrm{HR}=0.58$, $95 \%$ CI $0.39-0.85, p=0.0049$ ) (7). Final results of the CLEOPATRA study showed 8-year overall survival rates of $37 \%(95 \%$ CI 31-42) in the pertuzumab group and $23 \%$ (95\% CI 19-28) in the placebo group (8).

In a real-life study, known as RePER, on the use of double anti-HER2 blockade first-line treatment, 21 of the 264 patients presented brain metastases at baseline. The rate of 2-year OS was $77.7 \%$ in those patients and $83.9 \%$ in patients without brain metastases (9).

\section{Antibody-drug conjugates}

\section{Trastuzumab-emtansine}

Trastuzumab-emtansine (T-DM1) is a conjugated monoclonal antibody bound with tubulin inhibitor maytansine (10). The EMILIA trial evaluated the efficacy of T-DM1 vs. lapatinib and capecitabine. This study included 95 patients with brain metastasis. In this subset of patients, T-DM1 has shown an increase in OS (hazard ratio $0.38, \mathrm{p}=0.008$, mean 26.8 vs. 12.9 months) (10). However, this data should be interpreted with caution since no increase in progression-free survival (PFS) was observed and, therefore, this difference in OS may be related to subsequent therapies and extracranial disease control (10).

In the KAMILLA study, the largest observational study of T-DM1-treated patients to date, patients with brain metastasis $(n=398)$ showed similar results to those without metastasis to this organ (PFS of about 7 months and OS of 27 months) (11). It is necessary to consider that this study excluded patients with neurological symptoms caused by brain metastases or with brainlimited metastasis. Special consideration needs to be given to the risk for radionecrosis associated with this agent (12).

\section{Anticorpos monoclonais}

\section{Pertuzumab}

Pertuzumab é um anticorpo monoclonal que impede a heterodimerização do recetor HER2 com outros recetores da família EGFR (8). O estudo que levou à sua aprovação no tratamento em primeira linha nos doentes com CM HER2+ metastático (CLEOPATRA) excluiu doentes com metástases cerebrais. No entanto, no seguimento destas pacientes, verificou-se que o tratamento com trastuzumab, pertuzumab e docetaxel não reduziu a incidência de metástases cerebrais, mas atrasou o seu aparecimento (11,9 meses no braço placebo versus 15 meses no braço tratado com pertuzumab, RP $=0,58,95 \%$ IC $0,39-0,85, p=0,0049)$ (7). Os resultados finais do estudo CLEOPATRA mostraram taxas de SG aos 8 anos de 37\% (95\% IC 31-42) no grupo pertuzumab e de $23 \%$ (95\% IC 19-28) no grupo placebo (8).

No RePER, um estudo de vida real sobre o uso do duplo bloqueio anti-HER2 em primeira linha, 21 das 264 pacientes apresentavam metástases cerebrais ao diagnóstico. A taxa de SG aos 2 anos foi de 77,7\% nestas pacientes e $83,9 \%$ em pacientes sem metástases cerebrais (9).

\section{Anticorpos monoclonais conjugados}

\section{Trastuzumab-emtansina}

Trastuzumab-emtansina (T-DM1) é um anticorpo monoclonal conjugado com um inibidor da tubulina (10). O estudo EMILIA avaliou a eficácia do T-DM1 vs. lapatinib e capecitabina. Este estudo incluiu 95 pacientes com metástases cerebrais. Neste subgrupo de pacientes, o T-DM1 mostrou aumentar a SG (RR 0,38, $p=0,008$, média 26,8 vs. 12,9 meses) (10). No entanto, estes dados devem ser interpretados com cautela, uma vez que não se verificou aumento na sobrevivência livre de progressão (SLP) e, portanto, a diferença na SG pode estar relacionada com terapêuticas subsequentes e controlo da doença extracraniana.

No estudo KAMILLA, o maior estudo observacional de pacientes tratadas com T-DM1 até ao momento, doentes com metástases cerebrais $(n=398)$ mostraram resultados semelhantes àqueles sem metástase neste órgão (SLP de cerca de 7 meses e SG de 27 meses) (11). É necessário ter em conta que este estudo excluiu doentes com sintomas neurológicos. Deve ser especialmente considerado o risco de radionecrose associado a este agente (12). 


\section{Trastuzumab deruxtecan}

Trastuzumab deruxtecan is an antibody-drug conjugate composed of an anti-HER2 antibody, a cleavable tetrapeptide-based linker, and a cytotoxic topoisomerase I inhibitor (13).

The phase II DESTINY-Breast01 study (13) examined the efficacy of trastuzumab deruxtecan in patients with previously treated HER2 + BC who had received previous treatment with T-DM1. Data showed that in 184 patients who had undergone a median of six previous lines of treatment, the confirmed objective response rate (ORR) with trastuzumab deruxtecan was $60.3 \%$ and the median duration of response (DOR) was 14.8 months. The median PFS was 16.4 months $(95 \%$ CI, 12.7 to not reached) among all patients and 18.1 months (95\% CI, 6.7 to 18.1) among the 24 enrolled patients with treated and asymptomatic brain disease. Estimated OS at 6 months was $93.9 \%$ (95\% CI, 89.3 to 96.6$)$ and $86.2 \%(95 \% \mathrm{CI}, 79.8$ to 90.7$)$ at 12 months; median OS was not reached at the time of the publication. The most frequent grade 3 or 4 side effects were neutropenia $(20.7 \%)$, anaemia $(8.7 \%)$, and nausea $(7.6 \%)$. Adverse events that led to discontinuation included pneumonitis (in 11 patients) and interstitial lung disease (in 5 patients) (13).

\section{Small molecule tyrosine kinase inhibitors}

\section{Lapatinib}

Lapatinib is a reversible tyrosine kinase inhibitor of the EGFR (HER1) and HER2 receptors (14). In the LANDSCAPE clinical trial, Bachelot et al. investigated the role of the combination of lapatinib with capecitabine in 45 patients without previous WBRT treatment. The results showed a partial response to the lesions in $65.9 \%$ of cases and achieved an improvement of neurological symptoms in $58 \%$ of cases. The average time until progression to the brain was 5.5 months (14).

Lapatinib was also tested in combination with trastuzumab. Lin et al. (15) reported an objective brain response rate of $79 \%$ and a median OS of 19 months in a prospective study with 28 patients. Furthermore, Bartsch et al. (16) showed a significant prolongation of OS in the group treated with lapatinib and trastuzumab $(\mathrm{p}=0.002)$ in a retrospective study (25 patients).

The role of lapatinib to prevent brain metastases was tested in the CEREBEL trial, where patients were randomly assigned to receive lapatinib-capecitabine or trastuzumab-capecitabine (17). Brain metastases as the first site of relapse occurred in 3\% ( 8 of 251 patients)

\section{Trastuzumab deruxtecan}

Trastuzumab deruxtecan é um anticorpo monoclonal conjugado, constituído por um anticorpo anti-HER2, um ligando clivável tetrapeptídico e um citotóxico inibidor da topoisomerase I (13).

O estudo de fase II DESTINY-Breast01 (13) examinou a eficácia do trastuzumab deruxtecan em doentes com CM HER2 + previamente tratadas com T-DM1. Os dados mostraram que em 184 pacientes submetidas a uma média de seis linhas de tratamento, a taxa de resposta objetiva (TRO) foi de $60,3 \%$, e a duração média da resposta foi de 14,8 meses. A SLP média foi de 16,4 meses (IC de 95\%, 12,7 a não alcançado) entre todos doentes e 18,1 meses (IC de 95\%, 6,7 a $18,1)$ entre as 24 doentes com metástases cerebrais já previamente tratadas e assintomáticas. A SG aos 6 meses foi de $93,9 \%$ (IC de $95 \%, 89,3$ a 96,6 ) e $86,2 \%$ (IC de 95\%, 79,8 a 90,7) aos 12 meses; A SG média não foi alcançada até ao momento da publicação. Os efeitos secundários grau 3 ou 4 mais frequentes foram neutropenia $(20,7 \%)$, anemia $(8,7 \%)$ e náusea $(7,6 \%)$. Os efeitos adversos que levaram à descontinuação incluíram pneumonite (em 11 pacientes) e doença pulmonar intersticial (em 5 pacientes) (13).

\section{Pequenas moléculas inibidoras da tirosina cinase}

\section{Lapatinib}

Lapatinib é um inibidor reversível da tirosina cinase dos recetores EGFR (HER1) e HER2.14 No ensaio clínico LANDSCAPE, Bachelot et al. investigaram o papel da combinação de lapatinib com capecitabina em 45 pacientes sem tratamento prévio com radioterapia holocraneana. Os resultados mostraram resposta parcial em $65,9 \%$ dos casos e em $58 \%$ houve melhoria dos sintomas neurológicos. $\mathrm{O}$ tempo médio até à progressão a nível do cérebro foi de 5,5 meses (14).

Lapatinib também foi testado em combinação com trastuzumab. Lin et al. (15) relataram uma taxa de resposta objetiva a nivel cerebral de $79 \%$ e uma média do SG de 19 meses num estudo prospetivo com 28 pacientes. Além disso, Bartsch et al. (16) mostraram um prolongamento significativo da $\mathrm{SG}$ no grupo tratado com lapatinib e trastuzumab $(\mathrm{p}=0,002)$ num estudo retrospetivo (25 doentes).

O papel do lapatinib para prevenir metástases a nivel cerebral foi testado no estudo CEREBEL, no qual as pacientes foram aleatoriamente tratadas com lapatinibcapecitabina ou trastuzumab-capecitabina

(17) 
of the patients treated with lapatinib and 5\% (12 of 250 patients) in the trastuzumab group ( $95 \% \mathrm{CI},-2 \%$ to $5 \%$; $\mathrm{p}=0.360$ ). The trial was inconclusive for the primary endpoint.

\section{Neratinib}

Neratinib is an HER2 receptor tyrosine kinase inhibitor. It irreversibly inhibits the EGFR receptor (HER1), HER 2 and HER4 and demonstrated activity in the brain in two clinical trials $(18,19)$.

In the TBCRC 022 study, a phase 2 trial, 49 HER2+ $\mathrm{BC}$ patients with brain metastases were treated with neratinib and capecitabine. Twelve of the patients had previously been treated with lapatinib (18). The ORR was $33 \%$ and $49 \%$ in lapatinib-treated and lapatinibnaive patients, respectively. PFS in pre-treated and lapatinib-naive patients was 3.1 and 5.5 months, respectively, and OS was 15.1 and 13.3 months (18).

The NEfERT-T phase 3 trial (20) randomized 479 women to receive neratinib or trastuzumab combined with paclitaxel as first-line therapy for recurrent or metastatic HER2 disease (3). There was no significant difference in PFS, however, the neratinib group did have a lower incidence of brain recurrence (RR 0.48, 95\% CI, 0.29-0.79; $\mathrm{p}=0.002$ ), as well as a longer time to recurrence at this level (HR 0.45, 95\% CI, 0.26-0.78; p $=0.004)$. Grade 3 diarrhea was also a very common and relevant toxicity effect in the neratinib group (30.4\% vs. $3.8 \%)$.

In the NALA study, (19) a phase III clinical trial, 621 patients (including 101 patients with asymptomatic or stable brain metastases) were randomized into two groups. One group was treated with neratinib and capecitabine and the other group with lapatinib and capecitabine. The risk of progression or death was reduced by $24 \%$ with neratinib and capecitabine (HR $=0.76 ; 95 \%$ CI $0.63-0.93 ; \mathrm{p}=0.006)$. The PFS at 6 and 12 months was $47.2 \%$ vs $37.8 \%$ and $28.8 \%$ vs $14.8 \%$ for the neratinib + capecitabine and lapatinib + capecitabine groups, respectively. OS was also superior in the neratinib + capecitabine group, although not statistically significant $(\mathrm{HR}=0.88 ; 95 \%$ CI $0.72-$ 1.07; $\mathrm{p}=0.2086$ ). The incidence of intervention on symptomatic brain metastases was lower in the neratinib group (23\%) compared to the lapatinib group $(29 \%)$ (p $=0.043)$. Again, diarrhea was the most frequent toxicity effect related to neratinib in all clinical trials, being grade 3 in about $30 \%$ of the patients.
Metástases cerebrais como primeiro local de recidiva ocorreram em 3\% (8 de 251) das doentes tratadas com lapatinib e 5\% (12 de 250 doentes) no braço de trastuzumab (IC de $95 \%,-2 \%$ a $5 \%$; $=0,360$ ). O ensaio foi inconclusivo para o objetivo principal.

\section{Neratinib}

Neratinib é um inibidor da tirosina cinase do recetor HER2, que inibe irreversivelmente o recetor EGFR (HER1), HER2 e HER4 e demonstrou atividade ao nível cerebral em dois ensaios clínicos $(18,19)$

No estudo TBCRC 022, um ensaio de fase II, 49 doentes com CM com metástases cerebrais foram tratadas com neratinib e capecitabina, 12 das quais haviam sido tratadas anteriormente com lapatinib (18). A TRO foi de $33 \%$ e $49 \%$ em doentes tratadas com lapatinib e em doentes não tratadas com lapatinib, respetivamente. A SLP em pacientes pré-tratadas e não previamente tratadas com lapatinib foi de 3,1 e 5,5 meses, respetivamente, e a SG foi de 15,1 e 13,3 meses (18).

O estudo NEfERT-T de fase 3 (19) incluiu 479 mulheres e comparou neratinib ou trastuzumab em combinação com paclitaxel como terapêutica de primeira linha. Não houve diferença estatisticamente significativa na SLP. No entanto, o grupo tratado neratinib teve uma incidência mais baixa de metástases no cérebro (RR 0,48, IC de 95\%, 0,29-0,79; $\mathrm{p}=0,002$ ), bem como um tempo mais prolongado até recidiva a nível cerebral ( $\mathrm{RR}$ $0,45$, IC de 95\%, 0,26-0,78; $\mathrm{p}=0,004)$. A diarreia grau 3 foi também um efeito de toxicidade muito comum e relevante no grupo do neratinib (30,4\% vs. $3,8 \%)$.

No estudo NALA, (20) um ensaio clínico de fase III, 621 pacientes (incluindo 101 doentes com metástases cerebrais assintomáticas ou estáveis) foram aleatoriamente distribuídas em dois braços. Um grupo foi tratado com neratinib e capecitabina e o outro grupo com lapatinib e capecitabina. O risco de progressão ou morte foi reduzido em $24 \%$ com neratinib e capecitabina $(\mathrm{RR}=0,76$; IC 95\% 0,63-0,93; $\mathrm{p}=0,006)$. A SLP aos 6 e 12 meses foi de $47,2 \%$ vs $37,8 \%$ e $28,8 \%$ vs $14,8 \%$ para os grupos neratinib + capecitabina e lapatinib + capecitabina, respetivamente. A SG também foi superior no grupo neratinib + capecitabina, embora não estatisticamente significativa $(\mathrm{RR}=0,88$; IC 95\% 0,72$1,07 ; p=0,2086)$. A incidência de intervenção cirúrgica em metástases cerebrais sintomáticas foi menor no braço tratado com neratinib (23\%) em comparação com o braço do lapatinib $(29 \%)(\mathrm{p}=0,043)$. A diarreia foi o efeito de toxicidade mais frequente relacionado com o 


\section{Tucatinib}

Tucatinib is a tyrosine kinase inhibitor with a high affinity for the kinase domain of the HER 2 receptor and with minimal inhibition of the EGFR receptor, which improves the toxicity profile (21).

In the HER2CLIMB trial, 410 patients with progressing metastatic HER2 + BC after treatment with trastuzumab, pertuzumab, and TDM-1 were randomized to receive treatment with trastuzumab and capecitabine with or without tucatinib (21). About $48 \%$ of patients had brain metastases that did not require local approach therapies. PFS was superior with tucatinib vs. placebo (7.8 vs. 5.6 months; hazard ratio, 0.54$)$, as well as OS (21.9 vs. 17.4 months; HR, 0.66) and ORR (41\% vs 23\%). Among the patients with brain metastases, the estimated PFS at 1 year was $24.9 \%$ (95\% CI, 16.5 to 34.3$)$ in the tucatinib-combination group and $0 \%$ in the placebo combination group. The median duration of PFS was 7.6 months (95\% CI, 6.2 to 9.5) and 5.4 months (95\% CI, 4.1 to 5.7), respectively. In the tucatinib group, the most frequent adverse events included diarrhea, palmar-plantar erythrodysesthesia syndrome, fatigue, and nausea.

In a phase $1 \mathrm{~b}$ trial (22) the combination of tucatinib and T-DM1 showed an objective response rate of $36 \%$ in 14 patients with brain metastases ( 2 patients had a complete response, 3 had a partial response, 7 had stable disease, and 2 were non-evaluable). This combination is under evaluation, in a phase 3 trial (NCT03975647).

\section{Observational study}

Our sample included 44 Portuguese patients with HER+ breast carcinoma, submitted to neoadjuvant therapy with double anti-HER2 block with trastuzumab and pertuzumab, followed by surgery. The average age of the patients was 55 years. After neoadjuvant therapy, 18 patients underwent mastectomy and 26 underwent conservative surgery. The rate of complete pathological response in all patients was $61.4 \%$. The characterization of the patients according to their pathologic response is shown in Table 1. In patients who expressed hormone receptors $(n=34)$, the response rate was $58.8 \%$, while in HER2-enriched patients $(n=10)$ it was $70 \%$. Regarding the influence of the tumor size, the complete response rate was $80 \%$ in patients with $\mathrm{T} 1$ or $\mathrm{T} 2$ tumors and $45.8 \%$ in patients with $\mathrm{T} 3$ or $\mathrm{T} 4$. The rate of complete pathological response was $71.4 \%$ in patients without nodal involvement and $56.7 \%$ in patients with affected nodes. neratinib em todos os ensaios clínicos, sendo de grau 3 em cerca de $30 \%$ das doentes.

\section{Tucatinib}

Tucatinib é um inibidor da tirosina cinase com alta afinidade para o domínio cinase do recetor HER2 e com inibição mínima do recetor EGFR, o que melhora o perfil de toxicidade (21).

No ensaio HER2CLIMB, 410 doentes em progressão após tratamento com trastuzumab, pertuzumab e TDM-1 foram selecionadas para receber tratamento com trastuzumab e capecitabina com ou sem tucatinib (21). Cerca de $48 \%$ das doentes tinham doença a nível cerebral sem necessidade de terapêutica local. A SLP foi superior com tucatinib vs. placebo ( 7,8 vs. 5,6 meses; taxa de risco, 0,54), bem como SG (21,9 vs. $17,4$ meses; RR, 0,66) e TRO (41\% vs. $23 \%)$. Entre as doentes com metástases cerebrais, a SLP ao fim de 1 ano foi de $24,9 \%$ (IC de $95 \%, 16,5$ a 34,3 ) no grupo tratado com tucatinib e $0 \%$ no grupo placebo. A duração média da SLP foi de 7,6 meses (IC de 95\%, 6,2 a 9,5) e 5,4 meses (IC de 95\%, 4,1 a 5,7), respetivamente. No grupo do tucatinib, os efeitos adversos mais frequentes foram diarreia, síndrome da eritrodisestesia palmoplantar, fadiga e náuseas.

Num estudo de fase 1 b (22), a combinação de tucatinib e T-DM1 mostrou uma TRO de 36\% em 14 pacientes com metástases cerebrais ( 2 pacientes tiveram resposta completa, 3 resposta parcial, 7 tinham doença estável e 2 não avaliáveis). Esta combinação encontra-se a ser avaliada num estudo de fase 3 (NCT03975647).

\section{Estudo observacional}

A nossa amostra incluiu 44 doentes portuguesas com CM HER2+, submetidas a terapêutica neoadjuvante com duplo bloqueio anti-HER2 com trastuzumab e pertuzumab, seguida de cirurgia. A idade média dos doentes foi de 55 anos. Após terapêutica neoadjuvante, 18 doentes foram submetidas a mastectomia e 26 a cirurgia conservadora. A taxa de resposta patológica completa em todas as doentes foi de $61,4 \%$. A caracterização dos doentes de acordo com a resposta patológica é apresentada na Tabela 1 . Nos doentes que expressaram recetores hormonais $(\mathrm{n}=34)$, a taxa de resposta patológica completa foi de $58,8 \%$, enquanto que nos doentes com recetores hormonais negativos $(\mathrm{n}=10)$, a taxa de resposta foi de $70 \%$. Em relação à influência do tamanho do tumor, a taxa de resposta completa foi de $80 \%$ nas doentes com tumores $\mathrm{T} 1$ ou $\mathrm{T} 2$ e de $45,8 \%$ nas pacientes com T3 ou T4. A taxa de 
Table 1 - Characterization of the BC patients analyzed in this study. $\mathrm{pCR}$ - pathologic complete response; $\mathrm{cT}$ tumor classification by clinical stage; $\mathrm{cN}$ - lymph nodes affected by clinical stage

Tabela 1 - Caracterização dos doentes analisados neste estudo. RPC - resposta patológica completa; cT classificação do tumor por estadio clínico; $\mathrm{cN}$ - gânglios afetados por estadio clínico

No. of patients / No. de pacientes

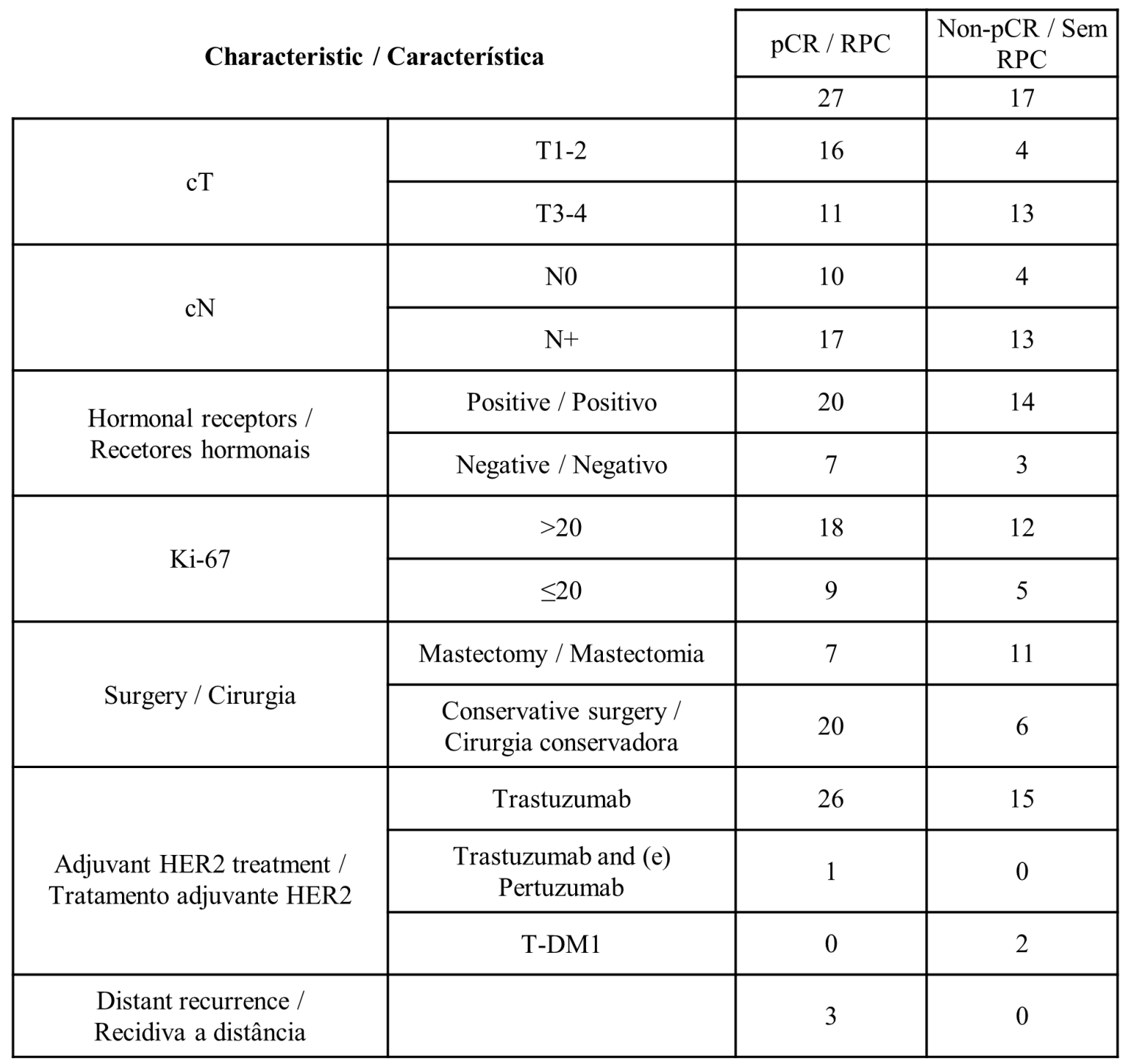

Case study of HER2 + BC patients with brain metastases

Of the 44 patients treated with neoadjuvant trastuzumab and pertuzumab with a mean follow-up of 23.9 months, three had a relapse, all at the brain level as the first site of metastasis. Interestingly, these three patients had shown a complete pathological response. The characterization of these patients is shown in Table 2. In Patient 1, relapse occurred 17.87 months after breast surgery. The brain lesion was resected, but, unfortunately, brain progression occurred one month after surgery. She resposta patológica completa foi de $71,4 \%$ em pacientes sem envolvimento ganglionar e $56,7 \%$ em pacientes com gânglios afectados.

Casos clínicos dos doentes com CM HER2+ com metástases cerebrais

Das 44 doentes tratadas com trastuzumab neoadjuvante e pertuzumab com seguimento médio de 23,9 meses, 3 apresentaram recidiva, todas a nível cerebral. Curiosamente, estas três doentes tinham obtido resposta 
Table 2 - Characterization of the BC patients with brain relapse in this study. T: trastuzumab; P: pertuzumab; L: lapatinib; C: capecitabine

Tabela 2 - Caracterização dos doentes com CM que apresentaram recidiva cerebral neste estudo. T: trastuzumab; P: pertuzumab; L: lapatinib; C: capecitabine

Patient 1 / Doente 1

Patient 2 / Doente 2

Patient 3 / Doente 3

\begin{tabular}{|c|c|c|c|}
\hline Stage at diagnosis / Estadio inicial & cT3N3 & $\mathrm{cT} 2 \mathrm{~N} 1$ & cT4N1 \\
\hline $\begin{array}{l}\text { Hormone receptor status / } \\
\text { Expressão de receptores hormonais }\end{array}$ & Negative / Negativo & Negative / Negativo & Negative / Negativo \\
\hline $\begin{array}{c}\text { Time between breast surgery and brain relapse / } \\
\text { Tempo entre a cirurgia da mama e a recidiva } \\
\text { cerebral }\end{array}$ & 17.87 months / meses & 7.16 months / meses & 6 days / dias \\
\hline $\begin{array}{l}\text { Surgery for brain metastases / } \\
\text { Cirurgia nas metástases cerebrais }\end{array}$ & Yes / Sim & No / Não & No / Não \\
\hline $\begin{array}{l}\text { 1st line treatment / } \\
1^{\mathrm{a}} \text { linha de tratamento }\end{array}$ & Docetaxel $+\mathrm{T}+\mathrm{P}$ & T-DM1 & T-DM1 \\
\hline $\begin{array}{c}\text { 2nd line treatment } / \\
2^{\mathrm{a}} \text { linha de tratamento }\end{array}$ & - & $\mathrm{L}+\mathrm{C}$ & $\mathrm{L}+\mathrm{C}$ \\
\hline $\begin{array}{l}\text { 3rd line treatment / } \\
3^{\mathrm{a}} \text { linha de tratamento }\end{array}$ & - & $\mathrm{T}+$ Vinorelbine & - \\
\hline $\begin{array}{c}\text { 4rd line treatment / } \\
4^{\mathrm{a}} \text { linha de tratamento }\end{array}$ & - & $\mathrm{T}+$ Gemcitabine & - \\
\hline $\begin{array}{l}\text { Overall survival (months) / } \\
\text { Sobrevivência global (meses) }\end{array}$ & 46.03 & 36.73 & 30.33 \\
\hline
\end{tabular}

received WBRT and then started systemic treatment. In Patients 2 and 3, brain relapse occurred soon after breast surgery. The three patients received WBRT and then started systemic treatment. To date, Patient 1 is under first-line treatment with trastuzumab and pertuzumab with stable disease and with no extra-brain disease. Patients 2 and 3 have died.

Only a few reports have examined risk factors for the development of brain metastases as the first site of metastatic disease in HER2+ breast cancer patients who received neoadjuvant treatment. In a cohort of 130 patients treated with neoadjuvant chemotherapy with trastuzumab and pertuzumab, the rate of BM as the first presentation of distant disease was 3.8\% (3/77) and 3.7\% patológica completa. A caracterização dessas pacientes é apresentada na Tabela 2. Na doente 1, a recidiva ocorreu 17,87 meses após a cirurgia do tumor primário. A metástase cerebral foi excisada, mas, infelizmente, apresentou recaída 1 mês após a cirurgia. Foi tratada posteriormente com radioterapia holocraneana e iniciou tratamento sistémico. Nas doentes 2 e 3, a recidiva cerebral ocorreu logo após a cirurgia de mama. As três doentes receberam radioterapia holocraneana e depois iniciaram tratamento sistémico. Até ao momento, a doente 1 está sob tratamento de $1^{\mathrm{a}}$ linha com trastuzumab e pertuzumab, com doença estável e sem doença extracerebral. As pacientes 2 e 3 faleceram.

Apenas alguns estudos verificaram quais os factores de risco para o desenvolvimento de metástases no cérebro em doentes com CM HER2+ como primeiro local derecidiva após terapêutica neoadjuvante. Numa coorte de 130 pacientes tratadas com quimioterapia neoadjuvante com trastuzumab e pertuzumab, a taxa de metástases cerebrais como primeiro local de 
$(2 / 53)$ in patients with pCR and non-pCR, respectively (23). However, the median time to development of BM was longer in patients with pCR (35 vs 11.7 months). In our cohort, brain relapse occurred in $1.1 \%(3 / 27)$ of patients with pCR. These three patients presented large tumors with nodal involvement, which is a risk factor for brain relapse (1). Overall survival of these patients was in accordance with previous studies (3).

In the Katherine study, the incidence of BM at the follow-up of 3 years was $5.9 \%$ in patients with residual disease who received TDM1 and $4.3 \%$ in patients who received trastuzumab (24). Our very small number of patients treated with adjuvant T-DM1 does not allow us to make conclusions about the effect of this treatment, but at the time of assessment, no patients had relapsed.

Also, the short period between surgery and brain recurrence in 2 out of 3 patients raises questions about the possibility of preexisting metastases at the time of surgery and whether there is a rationale for brain metastases screening in these patients. At this point, no recommendations can be made about this issue. Some current clinical trials are studying the role of brain MRIs in screening for brain metastases before the onset of symptoms and whether this will affect the overall prognosis and quality of life of patients (NCT03617341, NCT03881605, NCT04030507).

\section{Conclusions}

With the development of new molecules with activity in the brain, the biggest challenge is how to integrate surgery and radiotherapy in clinical treatment. As patient survival increases, the consequences of longterm treatments will be observed, namely the cognitive deterioration resulting from radiotherapy. Multiple prognostic models exist to help oncologists make decisions about patients who develop brain metastasis. One of the most used prognostic models is the Modified Breast Graded Prognostic Assessment (GPA), which confirmed that tumor receptor status, age, performance status, and number of BMs can predict OS (25).

Surgery will always play an important role, especially in the case of solitary brain lesions. It has the advantages of reducing tumor burden and allowing a revaluation of the immunochemistry markers. Discordance in hormone receptors and HER2 status between the recidiva foi de $3,8 \%(3 / 77)$ e $3,7 \%(2 / 53)$ em doentes com RPC e sem RPC, respetivamente (23). No entanto, o tempo médio para o desenvolvimento de metástases cerebrais foi maior em pacientes com RPC (35 vs 11,7 meses). Na nossa coorte, a recidiva cerebral ocorreu em $1,1 \%(3 / 27)$ das pacientes com RPC. Estas três doentes apresentavam grandes tumores com envolvimento ganglionar, o que constituem factores de risco para a recidiva cerebral (1). A SG destas pacientes esteve de acordo com estudos anteriores (3).

No estudo Katherine, a incidência de metástases cerebrais aos 3 anos de seguimento foi de 5,9\% nos doentes sem resposta patológica completa que foram tratados com TDM1 e $4.3 \%$ nos doentes tratados com trastuzumab (24). O reduzido número de doentes tratadas com T-DM1 adjuvante não nos permite concluir o efeito deste tratamento; contudo, no momento da avaliação, nenhum doente apresentou recidiva.

Além disso, o curto período entre a cirurgia e a recidiva cerebral em duas das três doentes levanta a questão sobre a possibilidade de metástases preexistentes no momento da cirurgia e se existe um papel para o rastreio de metástases cerebrais nestes doentes. Até agora, nenhuma recomendação pode ser feita sobre este tema. Alguns ensaios clínicos estão a analisar o papel da ressonância magnética cerebral no rastreio de metástases cerebrais antes do início dos sintomas, e se isso afectará o prognóstico geral e a qualidade de vida dos doentes (NCT03617341, NCT03881605, NCT04030507).

\section{Conclusões}

Com o desenvolvimento de novas moléculas com atividade no cérebro, o maior desafio está relacionado com a integração da cirurgia e da radioterapia no tratamento das metástases cerebrais. À medida que vamos aumentando a sobrevivência destas doentes veremos as consequências dos tratamentos a longo prazo, nomeadamente a deterioração cognitiva resultante dos tratamentos de radioterapia. Para auxiliar a decisão do oncologista, existem vários modelos de prognóstico para doentes com metástases cerebrais. Um dos modelos de prognóstico mais usados é o Graded Prognostic Assessment (GPA), o qual confirmou que o status de recetores do tumor, a idade, o estado geral do doente e número de metástases cerebrais podem prever a SG (25).

A cirurgia terá sempre um papel importante, especialmente no caso de lesões cerebrais solitárias. 
primary tumor and the metastatic lesion is well known. A large range of receptor discordance with ER, PR, and HER2 $(6-40 \%, 21-41 \%$, and $1-43 \%$, respectively) was described in a previous review (26). Radiosurgery is also an option for some unresectable brain metastases.

Current guidelines recommend that for patients with stable systemic disease at the time of BM diagnosis, the same systemic therapy should be continued, and BM should be treated with local therapy (surgery and/or radiotherapy). For patients with progressive systemic disease at the time of BM diagnosis, clinicians should use the algorithms for the treatment of HER+ metastatic $\mathrm{BC}$ (27). These guidelines may change in the very near future, and it may be wise for oncologists to change systemic therapies when brain recurrence occurs even with stable systemic disease. Trastuzumab deruxtecan or tucatinib can be considered in these cases.

Asymptomatic or lightly symptomatic patients with largely disseminated BM at diagnosis are normally referred for treatment with WBRT as a local therapy, however, this may not be the best choice. A change to systemic therapy may be more sensible, even with stable systemic disease, delaying radiotherapy until there is disease progression or there are symptoms related to metastasis. We will also see what role new targeted therapies like trastuzumab, deruxtecan, and tucatinib will play in early disease stages, when they might prevent or delay the onset of metastasis to the brain.

In this study, the neoadjuvant therapy with double anti-HER2 block using trastuzumab and pertuzumab led to higher rates of complete pathological response in patients with lower clinical stage and without nodal involvement. With a preliminary mean follow-up of 23.9 months, three patients (of 44 studied) had a relapse, and the brain was the first site of metastasis in all cases.

The brain may be ceasing to be the sanctuary that we thought it was. The appearance of new molecules with activities in the brain in HER2+ BC inspires new hope for the treatment of these patients. Further investigation is also needed in order to prevent HER2+ BC brain metastases.
Tem a vantagem de reduzir a carga tumoral e permitir uma reavaliação dos marcadores imunohistoquímicos. A discordância nos receptores hormonais e HER2 entre o tumor primário e as lesões metastáticas é bem conhecida. Uma revisão mostrou uma importante discordância dos receptores de estrogénio, progesterona e HER2 (6-40\%, 21-41\% e 1-43\%, respetivamente) (26). A radiocirurgia também é uma opção para algumas metástases cerebrais irresecáveis.

As diretrizes atuais recomendam que, para doentes com doença sistémica estável no momento de progressão a nível cerebral, se mantenha o mesmo tratamento sistémico e se aplique tratamento local sobre as metástases (cirurgia e/ou radioterapia). Para doentes com doença sistémica em progressão no momento do diagnóstico das metástases cerebrais, deve ser alterada a terapêutica sistémica conforme os algoritmos recomendados (27). Talvez isto venha a alterar-se muito em breve, e provavelmente deveríamos mudar o tratamento sistémico em casos de recidiva cerebral mesmo com doença sistémica estável. Trastuzumab deruxtecan ou tucatinib podem ser considerados nestes casos.

O tratamento local das metástases cerebrais nem sempre será a melhor escolha, especialmente se o que temos a oferecer é a radioterapia holocraneana. Provavelmente fará sentido em doentes assintomáticas ou pouco sintomáticas, com várias metástases cerebrais ao diagnóstico, que normalmente seriam tratadas com radioterapia holocraneana, alterar o tratamento sistémico mesmo com doença sistémica estável, e reservar a radioterapia para quando houver progressão da doença ou sintomas relacionados com a presença de metástases. Veremos também que papel os novos fármacos como o trastuzumab deruxtecan e tucatinib terão em estadios iniciais, onde poderão prevenir ou retardar o aparecimento de metástases no cérebro.

Neste estudo, a terapia neoadjuvante com duplo bloqueio anti-HER2 com trastuzumab e pertuzumab levou a maiores taxas de resposta patológica completa em doentes com estadio clínico inferior e sem envolvimento ganglionar. Com um seguimento médio preliminar de 23,9 meses, 3 pacientes recairam, todas a nível cerebral como primeiro local de metastização.

O cérebro pode estar a deixar de ser o santuário que pensávamos. $\mathrm{O}$ aparecimento de novas moléculas com atividade no cérebro no cancro de mama HER2+ abre esperança no tratamento destes doentes. São também necessários mais estudos de forma a prevenir a ocorrência de metástases cerebrais no CM HER2+. 


\section{Authors Contributions Statement}

PL: Investigation, Methodology, Writing - Original Draft Preparation; EC: Investigation, Methodology, Writing - Original Draft Preparation; RG: Writing - Original Draft Preparation; MV: Investigation, Methodology, Writing - Original Draft Preparation; IF: Writing - Original Draft Preparation ; JM: Validation; BG: Validation ; SB: Validation ; JGC: Supervision, Writing - Review \& Editing; ASF: Supervision, Writing - Review \& Editing

\section{Funding}

The authors received no financial support for the research, authorship, or publication of this article.

\section{Conflict of Interests}

The authors report no conflicts of interest.

\section{Declaração sobre as contribuições do autor}

PL: Investigação, Metodologia, Escrita - Preparação do manuscrito; EC: Investigação, Metodologia, Escrita Preparação do manuscrito; RG : Escrita - Preparação do manuscrito; MV Investigação, Metodologia, Escrita - Preparação do manuscrito; IF : Escrita - Preparação do manuscrito; JM : Validação; BG : Validação ; SB : Validação ; JGC : Supervisão, Escrita - Revisão \& Edição; ASF : Supervisão, Escrita - Revisão \& Edição

\section{Financiamento}

Os autores não receberam qualquer apoio financeiro para a investigação, autoria ou publicação deste artigo.

\section{Conflito de Interesses}

Sem conflitos de interesse 


\section{References / Referências}

1. Maurer, C., Tulpin, L., Moreau, M., Dumitrescu, C., de Azambuja, E., Paesmans, M., Nogaret, J. M., Piccart, M. J., \& Awada, A. (2018). Risk factors for the development of brain metastases in patients with HER2-positive breast cancer. ESMO open, 3(6), e000440. https:// doi.org/10.1136/esmoopen-2018-000440

2. Kennecke, H., Yerushalmi, R., Woods, R., Cheang, M. C., Voduc, D., Speers, C. H., Nielsen, T. O., \& Gelmon, K. (2010). Metastatic behavior of breast cancer subtypes. Journal of Clinical Oncology :Official Journal of the American Society of Clinical Oncology, 28(20), 3271-3277. https://doi.org/10.1200/JCO.2009.25.9820

3. McKee, M. J., Keith, K., Deal, A. M., Garrett, A. L., Wheless, A. A., Green, R. L., Benbow, J. M., Dees, E. C., Carey, L. A., Ewend, M. G., Anders, C. K., \& Zagar, T. M. (2016). A Multidisciplinary Breast Cancer Brain Metastases Clinic: The University of North Carolina Experience. The Oncologist, 21(1), 16-20. https://doi.org/10.1634/theoncologist.2015-0328

4. Mehta, M. P., Rodrigus, P., Terhaard, C. H., Rao, A., Suh, J., Roa, W., Souhami, L., Bezjak, A., Leibenhaut, M., Komaki, R., Schultz, C., Timmerman, R., Curran, W., Smith, J., Phan, S. C., Miller, R. A., \& Renschler, M. F. (2003). Survival and neurologic outcomes in a randomized trial of motexafin gadolinium and whole-brain radiation therapy in brain metastases. Journal of Clinical Oncology: Official Journal of the American Society of Clinical Oncology, 21(13), 2529-2536. https://doi.org/10.1200/JCO.2003.12.122.

5. Suh, J. H., Stea, B., Nabid, A., Kresl, J. J., Fortin, A., Mercier, J. P., Senzer, N., Chang, E. L., Boyd, A. P., Cagnoni, P. J., \& Shaw, E. (2006). Phase III study of efaproxiral as an adjunct to whole-brain radiation therapy for brain metastases. Journal of Clinical Oncology: Official Journal of the American Society of Clinical Oncology, 24(1), 106-114. https://doi.org/10.1200/JCO.2004.00.1768

6. Borgelt, B., Gelber, R., Kramer, S., Brady, L. W., Chang, C. H., Davis, L. W., Perez, C. A., \& Hendrickson, F. R. (1980). The palliation of brain metastases: final results of the first two studies by the Radiation Therapy Oncology Group. International Journal of Radiation Oncology, Biology, Physics, 6(1), 1-9. https://doi.org/10.1016/0360-3016(80)90195-9

7. Swain, S. M., Baselga, J., Miles, D., Im, Y-H., Quah, C., Lee, L. F., \& Cortés, J. (2014). Incidence of central nervous system metastases in patients with HER2-positive metastatic breast cancer treated with pertuzumab, trastuzumab, and docetaxel: results from the randomized phase III study CLEOPATRA. Journal of Clinical Oncology: Official Journal of the American Society of Clinical Oncology, 25(6), 1116-1121. https://doi.org/10.1093/annonc/mdu133

8. Swain, S.M, Miles D., Kim, S-B, Im, Y-H., Im, S-A. Semiglazov, V., Ciruelos, E., Schneeweiss, A. Monturus, E., Clark, E., Knott, A. Restuccia, E., Benyunes, M., Cortes, J. (2019). End-of-study analysis from the phase III, randomized, double-blind, placebo-controlled CLEOPATRA study of first-line pertuzumab, trastuzumab, and docetaxel in patients with HER2-positive metastatic breast cancer. ASCO Annual Meeting. Abstract 1020. Presented June 2, 2019. Journal of Clinical Oncology: Official Journal of the American Society of Clinical Oncology, 37 (suppl; abstr 1020). https:// doi.org/10.1200/JCO.2019.37.15_suppl.1020

9. Gamucci, T., Pizzuti, L., Natoli, C., Mentuccia, L., Sperduti, I., Barba, M., Sergi, D., Iezzi, L., Maugeri-Saccà, M., Vaccaro, A., Magnolfi, E., Gelibter, A., Barchiesi, G., Magri, V., D'Onofrio, L., Cassano, A., Rossi, E., Botticelli, A., Moscetti, L., Omarini, C., ... Vici, P. (2019). A multicenter REtrospective observational study of first-line treatment with PERtuzumab, trastuzumab and taxanes for advanced HER2 positive breast cancer patients. RePer Study. Cancer Biology \& Therapy, 20(2), 192-200. https://doi.org/10.1080/153 84047.2018.1523095

10. Krop, I. E., Lin, N. U., Blackwell, K., Guardino, E., Huober, J., Lu, M., Miles, D., Samant, M., Welslau, M., \& Diéras, V. (2015). Trastuzumab emtansine (T-DM1) versus lapatinib plus capecitabine in patients with HER2-positive metastatic breast cancer and central nervous system metastases: a retrospective, exploratory analysis in EMILIA. Annals of Oncology: Official Journal of the European Society for Medical Oncology, 26(1), 113-119. https://doi.org/10.1093/annonc/mdu486

11. Montemurro F, Ellis P, Delaloge S. (2017). Safety and efficacy of trastuzumab emtansine (T-DM1) in 399 patients with central nervous system metastases: Exploratory subgroup analysis from the KAMILLA study. Abstract No. P1-12-10, 2016 San Antonio Breast Cancer Symposium. Cancer Research 77(4 Supplement) P1-12-10. https://doi.org/10.1158/1538-7445.SABCS16-P1-12-10

12. Stumpf, P. K., Cittelly, D. M., Robin, T. P., Carlson, J. A., Stuhr, K. A., Contreras-Zarate, M. J., Lai, S., Ormond, D. R., Rusthoven, C. G., Gaspar, L. E., Rabinovitch, R., Kavanagh, B. D., Liu, A., Diamond, J. R., Kabos, P., \& Fisher, C. M. (2019). Combination of Trastuzumab Emtansine and Stereotactic Radiosurgery Results in High Rates of Clinically Significant Radionecrosis and Dysregulation of Aquaporin-4. Clinical Cancer Research: An Official Journal of the American Association for Cancer Research, 25(13), 3946-3953. https://doi.org/10.1158/1078-0432.CCR-18-2851.

13. Modi, S., Saura, C., Yamashita, T., Park, Y. H., Kim, S. B., Tamura, K., Andre, F., Iwata, H., Ito, Y., Tsurutani, J., Sohn, J., Denduluri, N., Perrin, C., Aogi, K., Tokunaga, E., Im, S. A., Lee, K. S., Hurvitz, S. A., Cortes, J., Lee, C., ... DESTINY-Breast01 Investigators (2020). Trastuzumab Deruxtecan in Previously Treated HER2-Positive Breast Cancer. The New England Journal of Medicine, $382(7), 610-621$. https://doi.org/10.1056/NEJMoa1914510.

14. Bachelot, T., Romieu, G., Campone, M., Diéras, V., Cropet, C., Dalenc, F., Jimenez, M., Le Rhun, E., Pierga, J. Y., Gonçalves, A., Leheurteur, M., Domont, J., Gutierrez, M., Curé, H., Ferrero, J. M., \& Labbe-Devilliers, C. (2013). Lapatinib plus capecitabine in patients with previously untreated brain metastases from HER2-positive metastatic breast cancer (LANDSCAPE): a single-group phase 2 study. The Lancet. Oncology, 14(1), 64-71. https://doi.org/10.1016/S1470-2045(12)70432-1.

15. Lin, N. U., Freedman, R. A., Ramakrishna, N., Younger, J., Storniolo, A. M., Bellon, J. R., Come, S. E., Gelman, R. S., Harris, G. J., Henderson, M. A., Macdonald, S. M., Mahadevan, A., Eisenberg, E., Ligibel, J. A., Mayer, E. L., Moy, B., Eichler, A. F., \& Winer, E. P. (2013). A phase I study of lapatinib with whole brain radiotherapy in patients with Human Epidermal Growth Factor Receptor 2 (HER2)-positive breast cancer brain metastases. Breast Cancer Research and Treatment, 142(2), 405414. https://doi.org/10.1007/s10549-013-2754-0

16. Bartsch, R., Berghoff, A., Pluschnig, U., Bago-Horvath, Z., Dubsky, P., Rottenfusser, A., DeVries, C., Rudas, M., Fitzal, F., Dieckmann, K., Mader, R. M., Gnant, M., Zielinski, C. C., \& Steger, G. G. (2012). Impact of anti-HER2 therapy on overall survival in HER2-overexpressing breast cancer patients with brain metastases. British Journal of Cancer, 106(1), 25-31.https://doi.org/10.1038/bjc.2011.531. 
17. Pivot, X., Manikhas, A., Żurawski, B., Chmielowska, E., Karaszewska, B., Allerton, R., Chan, S., Fabi, A., Bidoli, P., Gori, S., Ciruelos, E., Dank, M., Hornyak, L., Margolin, S., Nusch, A., Parikh, R., Nagi, F., DeSilvio, M., Santillana, S., Swaby, R. F., ... Semiglazov, V.(2015). CEREBEL (EGF111438): A Phase III, Randomized, Open-Label Study of Lapatinib Plus Capecitabine Versus Trastuzumab Plus Capecitabine in Patients With Human Epidermal Growth Factor Receptor 2-Positive Metastatic Breast Cancer. Journal of Clinical Oncology : Official Journal of the American Society of Clinical Oncology, 33(14), 1564-1573. https:// doi.org/10.1200/JCO.2014.57.1794

18. Freedman, R. A., Gelman, R. S., Anders, C. K., Melisko, M. E., Parsons, H. A., Cropp, A. M., Silvestri, K., Cotter, C. M., Componeschi, K. P., Marte, J. M., Connolly, R. M., Moy, B., Van Poznak, C. H., Blackwell, K. L., Puhalla, S. L., Jankowitz, R. C., Smith, K. L., Ibrahim, N., Moynihan, T. J., O'Sullivan, C. C., ... Translational Breast Cancer Research Consortium (2019). TBCRC 022: A Phase II Trial of Neratinib and Capecitabine for Patients With Human Epidermal Growth Factor Receptor 2-Positive Breast Cancer and Brain Metastases. Journal of Clinical Oncology : Official Journal of the American Society of Clinical Oncology, 37(13), 1081-1089. https:// doi.org/10.1200/JCO.18.01511

19. Awada, A., Colomer, R., Inoue, K., Bondarenko, I., Badwe, R. A., Demetriou, G., Lee, S. C., Mehta, A. O., Kim, S. B., Bachelot, T., Goswami, C., Deo, S., Bose, R., Wong, A., Xu, F., Yao, B., Bryce, R., \& Carey, L. A. (2016). Neratinib Plus Paclitaxel vs Trastuzumab Plus Paclitaxel in Previously Untreated Metastatic ERBB2-Positive Breast Cancer: The NEfERT-T Randomized Clinical Trial. JAMA Oncology, 2(12), 1557-1564. https://doi.org/10.1001/jamaoncol.2016.0237

20. Saura, C., Oliveira, M., Feng, Y. H., Dai, M. S., Chen, S. W., Hurvitz, S. A., Kim, S. B., Moy, B., Delaloge, S., Gradishar, W., Masuda, N., Palacova, M., Trudeau, M. E., Mattson, J., Yap, Y. S., Hou, M. F., De Laurentiis, M., Yeh, Y. M., Chang, H. T., Yau, T., ... NALA Investigators (2020). Neratinib Plus Capecitabine Versus Lapatinib Plus Capecitabine in HER2-Positive Metastatic Breast Cancer Previously Treated With $\geq 2$ HER2-Directed Regimens: Phase III NALA Trial. Journal of Clinical Oncology : Official Journal of the American Society of Clinical Oncology, 38(27), 3138-3149. https://doi.org/10.1200/JCO.20.00147

21. Murthy, R. K., Loi, S., Okines, A., Paplomata, E., Hamilton, E., Hurvitz, S. A., Lin, N. U., Borges, V., Abramson, V., Anders, C., Bedard, P. L., Oliveira, M., Jakobsen, E., Bachelot, T., Shachar, S. S., Müller, V., Braga, S., Duhoux, F. P., Greil, R., Cameron, D., ... Winer, E. P.(2020). Tucatinib, Trastuzumab, and Capecitabine for HER2-Positive Metastatic Breast Cancer. The New England Journal of Medicine, 382(7), 597-609. https://doi.org/10.1056/NEJMoa1914609

22. Borges, V. F., Ferrario, C., Aucoin, N., Falkson, C., Khan, Q., Krop, I., Welch, S., Conlin, A., Chaves, J., Bedard, P. L., Chamberlain, M., Gray, T., Vo, A., \& Hamilton, E. (2018). Tucatinib Combined With Ado-Trastuzumab Emtansine in Advanced ERBB2/HER2-Positive Metastatic Breast Cancer: A Phase 1b Clinical Trial. JAMA oncology, 4(9), 1214-1220. https://doi.org/10.1001/jamaoncol.2018.1812

23. Ferraro, E., Barrio, A.V., Patil, S., Robson, M. E., Dang, C. T. (2020) Incidence of brain metastases in patients receiving neoadjuvant chemotherapy (NAC) with trastuzumab and pertuzumab (HP) in HER2-positive early breast cancer (BC). Journal of Clinical Oncology : Official Journal of the American Society of Clinical Oncology, 38(15)_suppl. https://doi.org/10.1200/ JCO.2020.38.15_suppl.e12653.

24. von Minckwitz, G., Huang, C. S., Mano, M. S., Loibl, S., Mamounas, E. P., Untch, M., Wolmark, N., Rastogi, P., Schneeweiss, A., Redondo, A ., Fischer, H. H., Jacot, W., Conlin, A. K., Arce-Salinas, C., Wapnir, I. L., Jackisch, C., DiGiovanna, M. P., Fasching, P. A., Crown, J. P., Wülfing, P., ... KATHERINE Investigators (2019). Trastuzumab Emtansine for Residual Invasive HER2-Positive Breast Cancer. The New England Journal of Medicine, 380(7), 617-628. https://doi.org/10.1056/NEJMoa1814017.

25. Subbiah, I. M., Lei, X., Weinberg, J. S., Sulman, E. P., Chavez-MacGregor, M., Tripathy, D., Gupta, R., Varma, A., Chouhan, J., Guevarra, R. P., Valero, V., Gilbert, M. R., \& Gonzalez-Angulo, A. M. (2015). Validation and Development of a Modified Breast Graded Prognostic Assessment As a Tool for Survival in Patients With Breast Cancer and Brain Metastases. Journal of Clinical Oncology: Official Journal of the American Society of Clinical Oncology, 33(20), 2239-2245. https://doi.org/10.1200/JCO.2014.58.8517

26. Criscitiello, C., André, F., Thompson, A. M., De Laurentiis, M., Esposito, A., Gelao, L., Fumagalli, L., Locatelli, M., Minchella, I., Orsi, F., Goldhirsch, A., \& Curigliano, G. (2014). Biopsy confirmation of metastatic sites in breast cancer patients: clinical impact and future perspectives. Breast Cancer Research: BCR, 16(2), 205. https://doi.org/10.1186/bcr3630

27. Cardoso, F., Senkus, E., Costa, A., Papadopoulos, E., Aapro, M., André, F., Harbeck, N., Aguilar Lopez, B., Barrios, C. H., Bergh, J., Biganzoli, L., Boers-Doets, C. B., Cardoso, M. J., Carey, L. A., Cortés, J., Curigliano, G., Diéras, V., El Saghir, N. S., Eniu, A., Fallowfield, L., ... Winer, E. P. (2018). 4th ESO-ESMO International Consensus Guidelines for Advanced Breast Cancer (ABC 4) $\dagger$. Annals of Oncology: Official Journal of the European Society for Medical Oncology, 29(8), 1634-1657. https://doi.org/10.1093/ annonc/mdy192. 